\title{
MIR211 Pre-miRNA
}

National Cancer Institute

\section{Source}

National Cancer Institute. MIR211 Pre-miRNA. NCI Thesaurus. Code C98178.

MIR211 pre-microRNA (110 bases) is encoded by the human MIR211 gene. This

oligoribonucleotide has a role in the regulation of gene expression. 